\title{
Theoretical Energy and Exergy Analyses of Proton Exchange Membrane Fuel Cell by Computer Simulation
}

\author{
I. D. Gimba, ${ }^{1}$ A. S. Abdulkareem, ${ }^{1,2}$ A. Jimoh, ${ }^{1}$ and A. S. Afolabi ${ }^{3}$ \\ ${ }^{1}$ Department of Chemical Engineering, School of Engineering and Engineering Technology, Federal University of Technology, \\ PMB 65, Gidan Kwano, Minna, Niger State, Nigeria \\ ${ }^{2}$ Energy Research Group, Centre for Genetic Engineering and Biotechnology, Federal University of Technology, PMB 65, Bosso, \\ Minna, Niger State, Nigeria \\ ${ }^{3}$ Department of Chemical, Metallurgical and Materials Engineering, Botswana International University of \\ Science and Technology (BIUST) Plot 10071, Boseja, Palapye, Botswana
}

Correspondence should be addressed to A. S. Afolabi; afolabia@biust.ac.bw

Received 25 April 2016; Revised 21 July 2016; Accepted 7 August 2016

Academic Editor: Junsheng Yu

Copyright (C) 2016 I. D. Gimba et al. This is an open access article distributed under the Creative Commons Attribution License, which permits unrestricted use, distribution, and reproduction in any medium, provided the original work is properly cited.

\begin{abstract}
A mathematical model of a proton exchange membrane fuel cell (PEMFC) was developed to investigate the effects of operating parameters such as temperature, anode and cathode pressures, reactants flow rates, membrane thickness, and humidity on the performance of the modelled fuel cell. The developed model consisted of electrochemical, heat energy and exergy components which were later simulated using a computer programme. The simulated model for the voltage output of the cell showed good conformity to the experimental results sourced from the literature and revealed that the operating pressure, temperature, and flow rate of the reactants positively affect the performance and efficiencies (energy and exergy) of the cell. The results also indicated that high membrane thickness above $150 \mu \mathrm{m}$ is unfavourable to both the fuel cell performance and the cell energy and exergy efficiencies. The simulated results obtained on the influence of membrane humidity on the cell performance indicated that membrane humidity positively favours both the performance and energy and exergy efficiencies of the cell. It can therefore be inferred that the performance of the PEMFC and energy and exergy efficiencies of the cell are greatly influenced by the operating pressure, temperature, membrane thickness, membrane humidity, and the flow rates of fuel and oxidant.
\end{abstract}

\section{Introduction}

Over the years, the world has been greatly dependent on virtually only one energy source known as fossil fuel which is nonbiodegradable and quite limited for its domestic and industrial utilization. This condition led to disparity in world's fossil fuel production and demand, which resulted in energy crisis due to scarcity in supply and price fluctuation $[1,2]$. The price instability and environmental pollution of fossil fuel are some of the major problems derived from over dependence on this source of energy. It is widely documented that the combustion of fossil fuel is harmful to human health as well as the environment and this resulted in increase in campaign for cleaner energy source in order to safeguard the environment and protect man from the inhalation of toxic substances [3]. For instance, it is a known fact that the exhaust from the combustion of fossil fuel emits harmful gases such as $\mathrm{CO}_{2}, \mathrm{CO}$, and $\mathrm{SO}_{2}$ into the atmosphere $[1,4]$. These gases constitute severe health and environmental hazard and, hence, create a serious global environmental problem [5]. The concern for the price instability due to excessive reliance on fossil fuel and increasing awareness on the environmental impact of burning fossil fuel has led to increased calls for alternative energy sources that can compete well with the existing sources of energy $[6,7]$. Fuel cells which are described as electrochemical devices that convert the energy of a chemical reaction directly into electricity, with water as its by-product, are now considered promising, economical, and sustainable alternative energy source [8-10].

Fuel cells produce little or no pollutants depending on the type of fuel used [11]. They also have an advantage that makes them better than some industrial combustion which 
is their ability to capture excess heat generated and use it in a cogeneration-like manner or for space/water heating $[12,13]$. Other major advantages that fuel cells hold over internal combustion engines include the high efficiency of operation and lack of harmful pollutant emission. Despite researchers and government accorded recognition to fuel cells particularly the proton exchange membrane fuel cell (PEMFC) as the environmentally friendly alternative energy source that can compete well with the existing energy sources, the high cost of its allied parts and monopoly of the technology have hindered the commercial availability of fuel cells as alternative energy sources [14-16]. In the past few years, good progress has been made to achieve the commercialization of this alternative energy source by reducing the cost of the cell components which are made of the electrode, flow field plate, and membrane [17]. However, lack of understanding of the influence of various parameters on the rate of production of energy by the fuel cell system remains a serious issue which is the focus of this present study. On this note, the first and second laws of thermodynamics have been recognised as major tools for measuring the energy and exergy of the fuel cell technologies [18].

The first law of thermodynamics (energy analysis) deals with the quantity of energy and states that energy can neither be created nor destroyed. The law merely serves as a necessary tool for accounting for the energy during a process and offers no challenges to engineers. The second law (exergy analysis), however, deals with the quality of energy, degradation of this energy during a process, entropy generation, and lost opportunities to do work and offers plenty of room for improvement. The second law of thermodynamics has been proven to be a powerful tool in the optimization of complex thermodynamic systems [19-21]. In recent times, exergy analysis has become a key aspect in providing a better understanding for the analysis of power system processes, the quantification of sources of inefficiencies, and distinguishing quality of energy (or heat) used [22-24].

The aim of this study is therefore to develop a predictive mathematical model to determine the quantity of energy that can be produced by fuel cells as a function of operating parameters. Simulation of the developed model is expected to provide information on the interaction of various parameters that affect the performance of proton exchange membrane fuel cell.

\section{Conceptualization of the Modelling Technique}

This study is focused on the theoretical mathematical model that can be used to quantify the performance of a fuel cell as a function of operating parameters. The mathematical model will consist of electrochemical, heat energy and exergy analysis components. The following assumptions were made in developing the predictive model:

(i) There is incomplete utilization of the fuel and oxidant gases during the reaction process. (ii) The voltage losses encountered are activation polarization, ohmic polarization, and concentration polarization.

(iii) The enthalpy calculations are based on standard temperature.

(iv) The heat losses in the system are by natural convection, forced convection, and radiation.

Equations (1)-(3) represent the reactions taking place in a typical PEMFC system [13]:

$$
\begin{aligned}
\text { anode: } 2 \mathrm{H}_{2} & \longrightarrow 4 \mathrm{H}^{+}+4 \mathrm{e}^{-} \\
\text {cathode: } \mathrm{O}_{2}+4 \mathrm{H}^{+}+4 \mathrm{e}^{-} & \longrightarrow 2 \mathrm{H}_{2} \mathrm{O} \\
\text { overall: } 2 \mathrm{H}_{2}+\mathrm{O}_{2} & \longrightarrow 2 \mathrm{H}_{2} \mathrm{O} .
\end{aligned}
$$

The actual (or net) output voltage of the PEMFC, $V_{\text {cell }}$ as a function of current, temperature, partial pressure of reactant, and membrane humidity can be expressed as follows:

$$
V_{\text {cell }}=E_{\text {Nernst }}-\eta_{\text {act }}-\eta_{\text {ohmic }}-\eta_{\text {conc }} \text {, }
$$

where $E_{\text {Nernst }}$ is the thermodynamic equilibrium potential or open circuit voltage and $\eta_{\text {act }}, \eta_{\text {ohmic }}$, and $\eta_{\text {conc }}$ are activation, ohmic, and concentration overvoltages, respectively. Other names for overvoltages are polarization or losses, and they represent voltage drop.

The reversible cell voltage or thermodynamic potential is the maximum voltage attained from a fuel cell at thermodynamic equilibrium which can be obtained by applying the Nernst equation as shown as follows:

$$
E_{\mathrm{Nernst}}=V^{\circ}+\frac{R T}{n F} \ln \left[\frac{p_{\mathrm{H}_{2}}^{\prime}\left(p_{\mathrm{O}_{2}}^{\prime}\right)^{0.5}}{p_{\mathrm{H}_{2} \mathrm{O}}^{\prime}}\right] \text {, }
$$

where $V^{\circ}$ is the standard state reference potential $(298.15 \mathrm{~K}$ and $1 \mathrm{~atm})$ at unit activity, $p_{\mathrm{H}_{2}}^{\prime}, p_{\mathrm{O}_{2}}^{\prime}$, and $p_{\mathrm{H}_{2} \mathrm{O}}^{\prime}$ are partial pressures of hydrogen, oxygen, and water, respectively, $R$ is the universal gas constant $(8.314 \mathrm{~J} /$ mole $\mathrm{K}), T$ is the cell operating temperature $(\mathrm{K}), F$ is the Faraday constant $(96,485 \mathrm{C} / \mathrm{mole})$, and $n$ represents the number of moles of electrons transferred, having a value of 2 .

Equation (4) shows that part of the voltage is lost in driving the chemical reaction at the electrodes. This lost voltage is known as activation overvoltage $\left(\eta_{\text {act }}\right)$ which occurs at both the anode and cathode. Activation overvoltage is however more predominant at cathode since the hydrogen oxidation is faster than oxygen reduction. A parametric equation for representing activation overvoltage as proposed by Uma [25] is shown in the following equation:

$$
\eta_{\mathrm{act}}=-\left[\xi_{1}+\xi_{2} T+\xi_{3} T\left[\ln \left(c^{*}{ }_{\mathrm{O}_{2}}\right)\right]+\xi_{4} T[\ln (i)]\right]
$$


The values of the parametric coefficients $\xi_{1}, \xi_{2}, \xi_{3}$, and $\xi_{4}$ are determined using linear regression analysis [26]. These values are

$$
\begin{aligned}
& \xi_{1}=-0.948 \\
& \xi_{2}=0.00286+0.0002 \ln (A)+4.3 \times 10^{-5} \ln \left(c^{*}{ }_{\mathrm{H}_{2}}\right) \\
& \xi_{3}=7.6 \times 10^{-5} \\
& \xi_{4}=-1.93 \times 10^{-4},
\end{aligned}
$$

where $c^{*}{ }_{\mathrm{H}_{2}}$ and $c^{*} \mathrm{O}_{2}$ are concentrations of hydrogen and oxygen, respectively, at the reaction sites, while $A$ is the active cell area.

The concentrations of hydrogen and oxygen at the electrode-membrane interface can be determined from Henry's law equation [27] of the forms expressed in the following two equations:

$$
\begin{aligned}
& c^{*}{ }_{\mathrm{H}_{2}}=p_{\mathrm{H}_{2}}^{\prime} 9.174 \times 10^{-7} \exp \left(\frac{-77}{T}\right) \\
& c^{*}{ }_{\mathrm{O}_{2}}=p_{\mathrm{O}_{2}}^{\prime} 1.97 \times 10^{-7} \exp \left(\frac{498}{T}\right) .
\end{aligned}
$$

Substituting the values of the parametric coefficients into (6), we obtain the expression in the following equation:

$$
\begin{aligned}
\eta_{\text {act }}= & -[-0.948 \\
& +\left\{0.00286+0.0002 \ln (A)+4.3 \times 10^{-5} \ln \left(c^{*}{ }_{\mathrm{H}_{2}}\right)\right\} \\
& \cdot T+\left\{7.6 \times 10^{-5} T\left[\ln \left(c^{*}{ }_{\mathrm{O}_{2}}\right)\right]\right\}-1.93 \\
& \left.\times 10^{-4} T[\ln (i)]\right] .
\end{aligned}
$$

$$
R_{\text {ionic }}=\frac{\left(181.6\left[1+0.03(i / A)+0.062(T / 303)^{2}(i / A)^{2.5}\right] /[\lambda-0.634-3(i / A)] \exp [4.18((T-303) / T)]\right) l_{\text {mem }}}{A} .
$$

Substituting (14) into (11), we also obtain $\eta_{\text {ohmic }}$ expression as follows:

$$
\eta_{\text {ohmic }}=i\left\{\frac{\left(181.6\left[1+0.03(i / A)+0.062(T / 303)^{2}(i / A)^{2.5}\right] /[\lambda-0.634-3(i / A)] \exp [4.18((T-303) / T)]\right) l_{\text {mem }}}{A}\right\} .
$$

The concentration overvoltage $\left(\eta_{\text {conc }}\right)$ is another factor that can also affect the performance of the fuel cell. As reactant is consumed at the electrode by electrochemical reaction, there is a loss of potential due to the inability of the surrounding material to maintain the initial concentration of the bulk fluid (formation of concentration gradient) [28]. Several processes that may contribute to concentration polarization
The voltage loss as a result of resistance to the flow of electrons through the electrodes and various interconnections and resistance to the flow of ions through the electrolyte is known as ohmic overvoltage $\left(\eta_{\text {ohmic }}\right)$ which can be expressed as follows:

$$
\eta_{\text {ohmic }}=i R=i\left(R_{\text {electronic }}+R_{\text {ionic }}\right) .
$$

It has been reported that the resistance to flow of ions $\left(R_{\text {ionic }}\right)$ is predominant; hence, its contribution to ohmic overvoltage is more significant than the resistance to the flow of electrons $\left(R_{\text {electronic }}\right)$ [26]. The ionic resistance is a function of the membrane water content which in turn is a function of temperature and current. Hence, the ionic resistance can be expressed as follows [28]:

$$
R_{\text {ionic }}=\frac{r_{M} l_{\text {mem }}}{A},
$$

where $r_{M}$ is the membrane resistivity, $l_{\text {mem }}$ is the membrane thickness, and $A$ is the active cell area. The membrane resistivity in (12) was correlated by Rezazadeh et al. [26] as shown in the following equation:

$$
=\frac{181.6\left[1+0.03(i / A)+0.062(T / 303)^{2}(i / A)^{2.5}\right]}{[\lambda-0.634-3(i / A)] \exp [4.18((T-303) / T)]} .
$$

Substituting the expression in (13) into (12), we obtain the following: 
the electrochemical reaction site is a major contributor to concentration polarization. Concentration overpotential can be expressed as follows:

$$
\eta_{\text {conc }}=-B \ln \left(1-\frac{J}{J_{\max }}\right),
$$

where $B$ is a parametric coefficient and $J$ represents the actual current density of the cell $\left(\mathrm{A} / \mathrm{cm}^{2}\right)$. Substituting (5), (10), (15), and (16) into (4) gives a generalized equation for voltage output of the cell, $V_{\text {cell }}$, as follows:

$$
\begin{aligned}
V_{\text {cell }}= & \left\{V^{\circ}+\frac{R T}{n F} \ln \left[\frac{p_{\mathrm{H}_{2}}^{\prime}\left(p_{\mathrm{O}_{2}}^{\prime}\right)^{0.5}}{p_{\mathrm{H}_{2} \mathrm{O}}^{\prime}}\right]\right\}-0.948+\left\{0.00286+0.0002 \ln (A)+4.3 \times 10^{-5} \ln \left(c^{*}{ }_{\mathrm{H}_{2}}\right)\right\} T \\
& +\left\{7.6 \times 10^{-5} T\left[\ln \left(c^{*}{ }_{\mathrm{O}_{2}}\right)\right]\right\}-1.93 \times 10^{-4} T[\ln (i)] \\
& -i\left\{\frac{\left(181.6\left[1+0.03(i / A)+0.062(T / 303)^{2}(i / A)^{2.5}\right] /[\lambda-0.634-3(i / A)] \exp [4.18((T-303) / T)]\right) l_{\mathrm{mem}}}{A}\right\} \\
& +B \ln \left(1-\frac{J}{J_{\max }}\right) .
\end{aligned}
$$

Equation (17) is the predictive model expression for the voltage output from PEMFC as a function of the operating parameters for a single fuel cell.

The actual efficiency of the fuel cell can be obtained from the expression shown as follows:

$$
\text { cell efficiency }=\frac{V_{\text {cell }}}{V_{c}} \times 100,
$$

where $V_{c}$ is the actual voltage having a value of about $1.23 \mathrm{~V}$, and $V_{\text {cell }}$ is determined from (17).

In practice, not all the reactants going into the system react completely as some fractions of the fuel pass through the cell without taking part in energy production process; hence, fuel utilization term is introduced in calculating the proton exchange membrane fuel cell efficiency [29].

The fuel utilization coefficient is given as follows:

$$
\delta_{f}=\frac{\text { mass of fuel }\left(\mathrm{H}_{2}\right) \text { reacted in the cell }}{\text { mass of fuel }\left(\mathrm{H}_{2}\right) \text { input into the cell }} \text {. }
$$

If (19) is substituted into (18), it gives the following expression:

$$
\text { cell efficiency }=\delta_{f} \frac{V_{\text {cell }}}{V_{c}} \times 100 \text {. }
$$

2.1. Mass Balance for the PEMFC. As a requisite to carrying out energy balance for the PEM fuel cell, material balance becomes necessary. The mass balance was performed based on the inflow and outflow of the reactants $\left(\mathrm{H}_{2}\right.$ and $\left.\mathrm{O}_{2}\right)$ into and out of the fuel cell system as shown in Figure 1.

Considering the fact that not all reactants that entered the fuel cell were utilized, the component material balance for hydrogen and oxygen can be written as follows:

$$
\begin{aligned}
& m_{\mathrm{H}_{2}, \text { in }}=m_{\mathrm{H}_{2}, \text { react }}+m_{\mathrm{H}_{2}, \text { out }} \\
& m_{\mathrm{O}_{2} \text {, in }}=m_{\mathrm{O}_{2}, \text { react }}+m_{\mathrm{O}_{2} \text {,out }},
\end{aligned}
$$

where $m_{\mathrm{H}_{2} \text {,in }}$ and $m_{\mathrm{O}_{2} \text {, in }}$ are the mass flow rates of hydrogen and oxygen entering the PEM fuel cell, respectively. In addition, $m_{\mathrm{H}_{2} \text {,out }}$ and $m_{\mathrm{O}_{2} \text {,out }}$ are the mass flow rates of hydrogen and oxygen from PEM fuel cell, respectively. They represent hydrogen purged out of the fuel cell and the unreacted oxygen, respectively. The mass balance of the reactants $\left(\mathrm{O}_{2}\right.$ and $\mathrm{H}_{2}$ ) requires the essential electrochemistry principles to calculate the hydrogen and oxygen consumption rates, $m_{\mathrm{H}_{2} \text {,react }}$ and $m_{\mathrm{O}_{2} \text {,react }}$, and the water production, $m_{\mathrm{H}_{2} \mathrm{O} \text {,out }}$, as functions of current density $i\left(\mathrm{~A} / \mathrm{cm}^{2}\right)$ and Faraday's constant [30].

Hydrogen reacts on the anode side; thus the consumption rate of hydrogen is given as

$$
m_{\mathrm{H}_{2}, \text { react }}=\zeta_{A} M_{\mathrm{H}_{2}} \frac{J A_{\text {cell }}}{2 F} \times 10^{-3},
$$

where $\zeta_{A}$ stands for the anode stoichiometry, $M_{\mathrm{H}_{2}}$ is the molecular weight of hydrogen, $J$ is the current density, $A_{\text {cell }}$ is the effective area of the cell, and $F$ is Faraday's constant. Similarly, the consumption rate of oxygen can be calculated from the following equation [30]:

$$
m_{\mathrm{O}_{2}, \text { react }}=\zeta_{C} M_{\mathrm{O}_{2}} \frac{J A_{\text {cell }}}{2 F} \times 10^{-3},
$$

where $\zeta_{C}$ represents the cathode stoichiometry and $M_{\mathrm{O}_{2}}$ is the molecular weight of oxygen.

Assuming water produced from the fuel cell to be liquid, water production rate can be expressed as follows:

$$
m_{\mathrm{H}_{2} \mathrm{O}, \text { out }}=M_{\mathrm{H}_{2} \mathrm{O}} \frac{J A_{\text {cell }}}{2 \mathrm{~F}} \times 10^{-3}
$$

where $M_{\mathrm{H}_{2} \mathrm{O}}$ represents the molecular weight of water.

Hydrogen and oxygen which leave the system unutilized, $m_{\mathrm{H}_{2} \text {,out }}$ and $m_{\mathrm{O}_{2} \text {,out }}$, respectively, will be determined from (21) and (22) as follows:

$$
m_{\mathrm{H}_{2}, \text { out }}=m_{\mathrm{H}_{2} \text {,in }}-m_{\mathrm{H}_{2}, \text { react }} \text {. }
$$




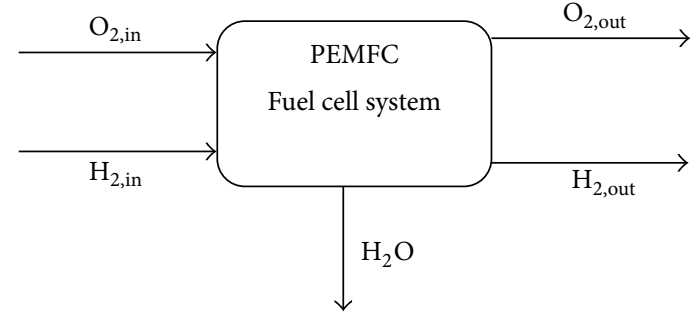

FIgURE 1: Schematic mass balances for the PEMFC.

Substituting for $m_{\mathrm{H}_{2} \text {,react }}$ gives

$$
m_{\mathrm{H}_{2}, \text { out }}=m_{\mathrm{H}_{2}, \text { in }}-\zeta_{A} M_{\mathrm{H}_{2}} \frac{J A_{\text {cell }}}{2 F} \times 10^{-3} .
$$

Similarly,

$$
\begin{aligned}
& m_{\mathrm{O}_{2}, \text { out }}=m_{\mathrm{O}_{2}, \text { in }}-m_{\mathrm{O}_{2}, \text { react }} \\
& m_{\mathrm{O}_{2}, \text { out }}=m_{\mathrm{O}_{2}, \text { in }}-\zeta_{\mathrm{C}} M_{\mathrm{O}_{2}} \frac{J A_{\text {cell }}}{2 \mathrm{~F}} \times 10^{-3} .
\end{aligned}
$$

Larminie and Dicks [31] give alternate equations for calculating the inlet mass flow rates of hydrogen and oxygen as shown in the following equations:

$$
\begin{aligned}
& m_{\mathrm{O}_{2}, \text { in }}=\text { oxygen }_{\text {in }}=3.57 \times 10^{-7}\left(\frac{\lambda_{s} \times W_{\text {net }}}{V_{\text {cell }}}\right) \\
& m_{\mathrm{H}_{2} \text {,in }}=\text { hydrogen }_{\text {in }}=1.05 \times 10^{-8}\left(\frac{W_{\text {net }}}{V_{\text {cell }}}\right) .
\end{aligned}
$$

Similarly, mass flow rates of unused oxygen and product water are given in expression in the following equations:

$$
\begin{aligned}
m_{\mathrm{O}_{2}, \text { out }}= & \text { oxygen }_{\text {out }} \\
= & 3.57 \times 10^{-7}\left(\frac{\lambda_{s} \times W_{\text {net }}}{V_{\text {cell }}}\right)-8.29 \\
& \times 10^{-8}\left(\frac{W_{\text {net }}}{V_{\text {cell }}}\right) \\
m_{\mathrm{H}_{2} \mathrm{O} \text { out }}= & \text { water }_{\text {out }}=9.34 \times 10^{-8}\left(\frac{W_{\text {net }}}{V_{\text {cell }}}\right),
\end{aligned}
$$

where $\lambda_{s}$ is the stoichiometry of oxygen.

2.2. Energy Analysis for the PEMFC. The conservation law of energy which is the first law of thermodynamics is used to analyze the energy model of the proton exchange membrane fuel cell. The energy balance around a fuel cell is based on the energy absorbing/releasing processes (power produced, reactions, and heat loss) that occur in the cell. As a result, the energy balance varies for the different types of cells because of the differences in reactions that occur according to the cell types.

The cell energy balance states that the enthalpy flow of reactants entering the cell will be equal to the enthalpy

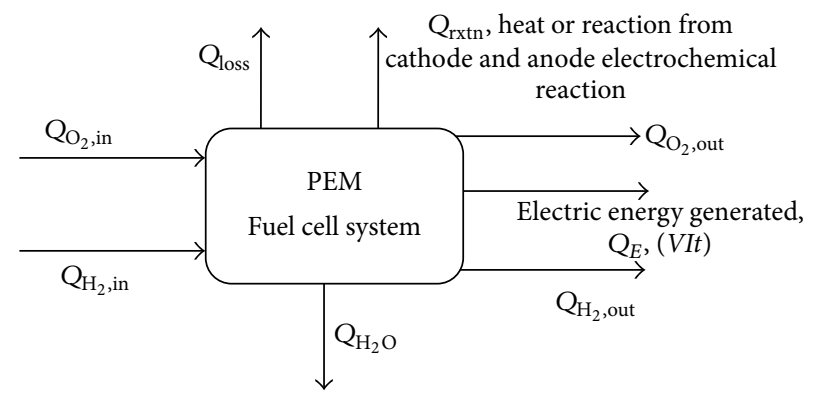

FIGURE 2: Schematic energy (enthalpy) balances for the PEMFC.

flow of the products leaving the cell plus the sum of three terms, namely, (i) the net heat generated by physical and chemical processes within the cell, (ii) the dc power output from the cell, and (iii) the rate of heat loss from the cell to its surroundings. The energy balance according to the heat flow into and out of the cell as shown in Figure 2 can be represented mathematically as follows:

$$
Q_{\text {input }}-Q_{\text {output }}-Q_{\text {acc }}=0 \text {, }
$$

where $Q_{\text {input }}$ and $Q_{\text {output }}$ are the total heat input and output, respectively, and $Q_{\text {acc }}$ is the heat accumulation which is the net heat generated by physical and chemical processes within the cell.

By replacing $Q_{\text {acc }}$ in (34) with $Q_{\text {net }}$ and rearranging, we obtain the following expression:

$$
Q_{\text {net }}=Q_{\text {input }}-Q_{\text {output }} \cdot
$$

From the schematic shown in Figure 2, the total heat input into the system is

$$
Q_{\text {input }}=Q_{\mathrm{H}_{2}, \text { in }}+Q_{\mathrm{O}_{2} \text {,in }},
$$

where $Q_{\mathrm{H}_{2} \text {,in }}$ and $Q_{\mathrm{O}_{2} \text {,in }}$ are the heats from the reactant feeds. Similarly, the total heat output from the system is as shown as follows:

$$
\begin{aligned}
Q_{\text {output }}= & Q_{\mathrm{H}_{2}, \text { out }}+Q_{\mathrm{O}_{2}, \text { out }}+Q_{\mathrm{H}_{2} \mathrm{O}}+Q_{\text {rxtn }}+Q_{E} \\
& +Q_{\text {loss }} .
\end{aligned}
$$

From (37), $Q_{\mathrm{H}_{2} \text {,out }}$ and $Q_{\mathrm{O}_{2} \text {,out }}$ are the heats from the unreacted hydrogen and oxygen, respectively, $Q_{\mathrm{H}_{2} \mathrm{O}}$ is the heat from water produced, $Q_{\mathrm{rxtn}}$ is the heat of reaction from cathode and anode electrochemical reaction, $Q_{\text {loss }}$ is the heat loss to the surroundings, and $Q_{E}$ is the electrical energy $\left(V_{\text {cell }} \times I t\right)$ generated.

The heat generated by the fuel cell system is transferred through the stack by conduction, which then dissipates into the surroundings using natural convection, forced convection, and radiation [30]. Hence, the three heat transfer mechanisms play important roles to transfer the heat from the fuel cell stack to the ambient. In addition, some heat is carried away from the fuel cell stack by the product gases and water. Heat lost termed $Q_{\text {loss }}$ from the fuel cell can be represented as follows:

$$
Q_{\text {loss }}=Q_{\mathrm{nc}}+Q_{\mathrm{fcn}}+Q_{\mathrm{rad}}
$$


where $Q_{\mathrm{nc}}, Q_{\mathrm{fcn}}$, and $Q_{\mathrm{rad}}$ are heat losses via natural convection, forced convection, and radiation, respectively. The expressions for $Q_{\text {cond }}, Q_{\mathrm{nc}}, Q_{\mathrm{fcn}}$, and $Q_{\mathrm{rad}}$ can be obtained by considering a fuel cell slab of solid material of area $A$ located between two large parallel plates at distance $Y$ apart; the rate of heat flow by conduction per unit area is given by Fourier expression as follows [32]:

$$
\frac{Q_{\text {cond }}}{A}=\kappa \frac{\Delta T}{Y} .
$$

That is, the rate of heat flow per unit area is proportional to the temperature decrease over the distance $Y$. The constant of proportionality к is the thermal conductivity of the slab. $\Delta T$ is given as $\left(T_{1}-T_{0}\right)$, where $T_{0}$ and $T_{1}$ are the initial temperature and the temperature at a steady-state condition of heat flow across the slab.

$Q_{\mathrm{nc}}$ and $Q_{\mathrm{fcn}}$ are calculated separately from (40) and (41), respectively:

$$
\begin{aligned}
Q_{\mathrm{nc}} & =h_{\mathrm{nc}} A_{\mathrm{FC}}\left(T_{\mathrm{FC}}-T_{0}\right) \\
Q_{\mathrm{fcn}} & =m_{\text {coolant }} C_{p, \text { air }}\left(T_{\text {coolant,out }}-T_{0}\right) .
\end{aligned}
$$

Air is used as coolant in fuel cells; $h_{\mathrm{nc}}$ is the natural convective heat transfer coefficient; $A_{\mathrm{FC}}$ is the total heat transfer area of the fuel cell; it can be estimated from the dimensions of the fuel cell system. $T_{0}$ is the ambient temperature which is assumed to be the dead state temperature of $298 \mathrm{~K}$.

For nonblack surfaces at temperature $T$, the emitted energy flux is given by Stefan-Boltzmann law [33] as

$$
Q_{\mathrm{rad}}=\varepsilon \sigma A_{\mathrm{FC}}\left(T_{\mathrm{FC}}^{4}-T_{0}^{4}\right),
$$

where $T$ is the absolute temperature and $A_{\mathrm{FC}}$ is the total heat surface area of the fuel cell system. The Stefan-Boltzmann constant $\sigma$ has been found to have the value of $5.67 \times$ $10^{-8} \mathrm{~W} / \mathrm{m}^{2} \mathrm{~K}^{4}$, and $\varepsilon$ is the emissivity having standard values for various materials.

Substituting (36) to (38) and (40) to (42) into (35) will yield

$$
\begin{aligned}
Q_{\text {net }}= & Q_{\mathrm{H}_{2}, \text { in }}+Q_{\mathrm{O}_{2}, \text { in }}-Q_{\mathrm{H}_{2}, \text { out }}-Q_{\mathrm{O}_{2}, \text { out }}-Q_{\mathrm{H}_{2} \mathrm{O}} \\
& -Q_{\mathrm{rxtn}}-Q_{E}-h_{\mathrm{nc}} A_{\mathrm{FC}}\left(T_{\mathrm{FC}}-T_{0}\right) \\
& -m_{\text {coolant }} C_{p \text {, air }}\left(T_{\text {coolant,out }}-T_{0}\right) \\
& -\varepsilon \sigma A_{\mathrm{FC}}\left(T_{\mathrm{FC}}^{4}-T_{0}^{4}\right) .
\end{aligned}
$$

Equation (43) can be rewritten in terms of enthalpies to yield the following equation:

$$
\begin{aligned}
Q_{\text {net }}= & \Delta H_{\mathrm{H}_{2}, \text { in }}+\Delta H_{\mathrm{O}_{2}, \text { in }}-\Delta H_{\mathrm{H}_{2}, \text { out }}-\Delta H_{\mathrm{O}_{2}, \text { out }} \\
& -\Delta H_{\mathrm{H}_{2} \mathrm{O}}-\Delta H_{\mathrm{rxtn}}-Q_{E} \\
& -h_{\mathrm{nc}} A_{\mathrm{FC}}\left(T_{\mathrm{FC}}-T_{0}\right) \\
& -m_{\text {coolant }} C_{p, \text { air }}\left(T_{\text {coolant,out }}-T_{0}\right) \\
& -\varepsilon \sigma A_{\mathrm{FC}}\left(T_{\mathrm{FC}}^{4}-T_{0}^{4}\right),
\end{aligned}
$$

where $\Delta H_{\mathrm{O}_{2}}, \Delta H_{\mathrm{H}_{2}}$, and $\Delta H_{\mathrm{H}_{2} \mathrm{O}}$ are the enthalpies of oxygen, hydrogen, and water, respectively, and $\Delta H_{\mathrm{rxtn}}$ is the enthalpy of reaction.

The electrical energy dissipated $Q_{E}$ is related to the net output voltage $V_{\text {cell }}$ by

$$
Q_{E}=V_{\text {cell }} \times I t,
$$

where $I$ is the current and $t$ is the duration of operation. Equation (44) can be rearranged to obtain

$$
\begin{aligned}
Q_{\text {net }}= & \Delta H_{\mathrm{H}_{2}, \text { in }}+\Delta H_{\mathrm{O}_{2}, \text { in }}-\Delta H_{\mathrm{H}_{2}, \text { out }}-\Delta H_{\mathrm{O}_{2}, \text { out }} \\
& -\Delta H_{\mathrm{H}_{2} \mathrm{O}}-\Delta H_{\mathrm{rxtn}}-V_{\text {cell }} I t \\
& -h_{\mathrm{nc}} A_{\mathrm{FC}}\left(T_{\mathrm{FC}}-T_{0}\right) \\
& -m_{\text {coolant }} C_{p, \text { air }}\left(T_{\text {coolant,out }}-T_{0}\right) \\
& -\varepsilon \sigma A_{\mathrm{FC}}\left(T_{\mathrm{FC}}^{4}-T_{0}^{4}\right)
\end{aligned}
$$

The enthalpy of reaction term, $\Delta H_{\text {rxtn }}$, in the energy balance equation is computed as follows [34]:

$$
\Delta H_{\mathrm{rxtn}}=\Delta H_{\mathrm{rxtn}}^{\circ}+\int_{298}^{T}\left(\Delta C_{p}\right) d T .
$$

Upon integration of (47), $\Delta H_{\mathrm{rxn}}$ becomes

$$
\Delta H_{\mathrm{rxtn}}=\Delta H_{\mathrm{rxtn}}^{\circ}+\Delta C_{p}(T-298),
$$

where $\Delta H_{\text {rxtn }}^{\circ}=\left(n_{i} \Delta H_{f_{i}}^{\circ}\right)_{\text {prdcts }}-\left(n_{i} \Delta H_{f_{i}}^{\circ}\right)_{\text {rxtnts }}$.

For the PEMFC, where $2 \mathrm{H}_{2}+\mathrm{O}_{2} \rightarrow 2 \mathrm{H}_{2} \mathrm{O}, 2$ moles of $\mathrm{H}_{2}$ and 1 mole of $\mathrm{O}_{2}$ give 2 moles of $\mathrm{H}_{2} \mathrm{O}$ :

$$
\begin{aligned}
\Delta H_{\text {rxtn }}^{\circ}= & \left(2 \times \Delta H_{f_{\mathrm{H}_{2} \mathrm{O}}}^{\circ}\right)_{\text {prdcts }} \\
& -\left[\left(2 \times \Delta{H^{\circ}{ }_{\mathrm{H}_{2}}}^{\circ}\right)+\left(1 \times \Delta{H^{\circ}}_{f_{\mathrm{O}_{2}}}\right)\right]_{\text {rxtnts }} .
\end{aligned}
$$

And also from the reaction stoichiometry,

$$
\begin{aligned}
\Delta C_{p}= & \left(2 \times \Delta C_{p_{\mathrm{H}_{2} \mathrm{O}}}\right)_{\text {prdcts }} \\
& -\left[\left(2 \times \Delta C_{p_{\mathrm{H}_{2}}}\right)+\left(1 \times \Delta C_{p_{\mathrm{O}_{2}}}\right)\right]_{\text {rxtnts }} .
\end{aligned}
$$

Therefore, the energy efficiency of the PEMFC system is

$$
\eta_{\text {energy,system }}=\frac{\widehat{W}_{\text {net }}}{\mathrm{HHV}_{\mathrm{H}_{2}} \times m_{\mathrm{H}_{2}, \text { in }}} .
$$

Higher heating value of a fuel (HHV) is the negative value of the standard heat of combustion when water in the combustion products is in form of a liquid [35]. Here, $\mathrm{HHV}_{\mathrm{H}_{2}}$ is the higher heating value of hydrogen, $W_{\text {net }}\left(V_{\text {cell }} \times I\right)$ is the net power production of the fuel cell system, and $m_{\mathrm{H}_{2} \text {,in }}$ is the mass flow rate of hydrogen to the PEMFC. 
2.3. Exergy Analysis. The flow exergy of a substance refers to the theoretically obtainable work when that substance is brought to total equilibrium with the local environment. It can be divided into thermomechanical and chemical flow exergies [36]. Hence, the total exergy rate can be written as

$$
\widehat{E}=\widehat{E}_{\mathrm{tm}}+\widehat{E}_{\mathrm{CH}} .
$$

The thermomechanical exergy is also known as physical exergy, and it represents the deviation in temperature and pressure between the flowing matter and the ambient. It also includes the kinetic and potential exergies. However, the chemical exergy represents the deviation in chemical composition between the flowing matter and the local environment. Therefore, (52) becomes

$$
\widehat{E}=\widehat{E}_{\mathrm{ke}}+\widehat{E}_{\mathrm{pe}}+\widehat{E}_{\mathrm{tm}}+\widehat{E}_{\mathrm{CH}} .
$$

Amir et al. [37] also give the specific total exergy $(\mathrm{J} / \mathrm{kg})$ as the sum of kinetic exergy, potential exergy, thermomechanical exergy, and chemical exergy as

$$
e=e_{\mathrm{ke}}+e_{\mathrm{pe}}+e_{\mathrm{tm}}+e_{\mathrm{CH}},
$$

where $e=\widehat{E} / m, \widehat{E}$ is the total exergy rate $(\mathrm{J} / \mathrm{hr})$, and $m$ represents the mass flow rate $(\mathrm{kg} / \mathrm{hr})$. Therefore, (54) becomes

$$
\widehat{E}=m e_{\mathrm{ke}}+m e_{\mathrm{pe}}+m e_{\mathrm{tm}}+m e_{\mathrm{CH}} .
$$

The specific kinetic exergy term, $e_{\mathrm{ke}}$, is expressed as

$$
e_{\mathrm{ke}}=\frac{1}{2} v^{2},
$$

where $v$ is the velocity relative to the earth surface $(\mathrm{m} / \mathrm{s})$; and the specific potential exergy term, $e_{\mathrm{pe}}$, is given by

$$
e_{\mathrm{pe}}=g Z \text {, }
$$

where $g$ is the earth gravity $\left(\mathrm{m} / \mathrm{s}^{2}\right)$ and $Z$ is the stream altitude above the sea level (m).

The thermomechanical exergy shown in (54) can be simplified as a function of fuel cell operating temperature and pressure [38] as

$$
e_{\mathrm{tm}}=\left(h-h_{0}\right)-T_{0}\left(s-s_{0}\right),
$$

where $h_{0}$ and $s_{0}$ represent the specific enthalpy $(\mathrm{J} / \mathrm{kg})$ and entropy $(\mathrm{J} / \mathrm{kg} \cdot \mathrm{K})$ at standard conditions, respectively; $\left(h-h_{0}\right)$ and $\left(s-s_{0}\right)$ are changes in enthalpy and entropy, respectively.

Meanwhile, Masanori and Abdelaziz [38] expressed the specific molar chemical exergy of component $i$ present in the environment at partial pressure $P_{00, i}$ as

$$
e_{\mathrm{CH}}=R T_{0} \ln \left(\frac{P_{0}}{P_{00, i}}\right)
$$

where $P_{0}$ is the environmental pressure (usually taken as $1 \mathrm{~atm}$ ) and $P_{00, i}$ is the partial pressure of the reference component and $R$ is the ideal gas constant.
Hence, substituting (56) to (59) into (54) yields an expression for the specific total exergy; thus,

$$
\begin{aligned}
e= & \frac{1}{2} v^{2}+g Z+\left(h-h_{0}\right)-T_{0}\left(s-s_{0}\right) \\
& +R T_{0} \ln \left(\frac{P_{0}}{P_{00, i}}\right) .
\end{aligned}
$$

The specific thermomechanical exergy term $\left(h-h_{0}\right)-T_{0}(s-$ $s_{0}$ ) of (58) can be evaluated further as a function of fuel cell operating condition:

$$
\begin{gathered}
\left(h-h_{0}\right)=\int_{T_{0}}^{T} C_{p}(T) d T=C_{p}\left(T-T_{0}\right) \\
\left(s-s_{0}\right)=\int_{T_{0}}^{T} \frac{C_{p}}{T} d T-\int_{P_{0}}^{P}\left(\frac{\partial V}{\partial T}\right) d P .
\end{gathered}
$$

Based on ideal gas assumption, $P \partial V=R \partial T$, so that

$$
\frac{\partial V}{\partial T}=\frac{R}{P}
$$

where $R$ is the universal gas constant; substituting (63) into (62) gives

$$
\left(s-s_{0}\right)=\int_{T_{0}}^{T} \frac{C_{p}}{T} d T-\int_{P_{0}}^{P}\left(\frac{R}{P}\right) d P .
$$

Integrating (63) yields

$$
\left(s-s_{0}\right)=C_{p} \ln \left(\frac{T}{T_{0}}\right)-R \ln \left(\frac{P}{P_{0}}\right) .
$$

Specific heats at constant pressure, $C_{p}$, and at constant volume, $C_{v}$, are related to $R$ as [32]

$$
\begin{gathered}
C_{p}=C_{v}+R \text { or } \\
R=C_{p}-C_{v} .
\end{gathered}
$$

Substituting for $R$ in (65),

$$
\left(s-s_{0}\right)=C_{p} \ln \left(\frac{T}{T_{0}}\right)-\left(C_{p}-C_{v}\right) \ln \left(\frac{P}{P_{0}}\right) .
$$

Rearrange (67) to obtain

$$
\left(s-s_{0}\right)=C_{p}\left[\ln \left(\frac{T}{T_{0}}\right)-\left(1-\frac{C_{v}}{C_{p}}\right) \ln \left(\frac{P}{P_{0}}\right)\right] .
$$

$C_{v} / C_{p}$ can be expressed in terms of the specific heat ratio, $k$; thus,

$$
\begin{aligned}
k & =\frac{C_{p}}{C_{v}} \text { or } \\
\frac{1}{k} & =\frac{C_{v}}{C_{p}} .
\end{aligned}
$$


Hence, (68) becomes

$$
\left(s-s_{0}\right)=C_{p}\left[\ln \left(\frac{T}{T_{0}}\right)-\left(\frac{k-1}{k}\right) \ln \left(\frac{P}{P_{0}}\right)\right] .
$$

Substituting (61) and (70) into (58) gives an expression for the specific thermomechanical (physical) exergy as

$$
\begin{aligned}
e_{\mathrm{tm}}= & C_{p}\left(T-T_{0}\right) \\
& -T_{0} C_{p}\left[\ln \left(\frac{T}{T_{0}}\right)-\left(\frac{k-1}{k}\right) \ln \left(\frac{P}{P_{0}}\right)\right] .
\end{aligned}
$$

Simplifying (71) further yields

$$
e_{\mathrm{tm}}=C_{p} T_{0}\left[\frac{T}{T_{0}}-1-\ln \left(\frac{T}{T_{0}}\right)+\ln \left(\frac{P}{P_{0}}\right)^{((k-1) / k)}\right] .
$$

By substituting (72) into (60) we obtain the total specific exergy:

$$
\begin{aligned}
e= & \frac{1}{2} v^{2}+g Z \\
& +C_{p} T_{0}\left[\frac{T}{T_{0}}-1-\ln \left(\frac{T}{T_{0}}\right)+\ln \left(\frac{P}{P_{0}}\right)^{((k-1) / k)}\right] \\
& +R T_{0} \ln \left(\frac{P_{0}}{P_{00, i}}\right) .
\end{aligned}
$$

Hence, substituting (73) into (55) gives the overall total exergy rate equation that can be used for calculating the exergy of each component in the model equation:

$\widehat{E}$

$$
\begin{aligned}
= & \frac{1}{2} m v^{2}+m g Z \\
& +m C_{p} T_{0}\left[\frac{T}{T_{0}}-1-\ln \left(\frac{T}{T_{0}}\right)+\ln \left(\frac{P}{P_{0}}\right)^{((k-1) / k)}\right] \\
& +m R T_{0} \ln \left(\frac{P_{0}}{P_{00, i}}\right) .
\end{aligned}
$$

From a thermodynamics point of view, the exergetic efficiency, which is known as second law efficiency, gives the true value of the performance of an energy system [39]. Exergy is defined as the maximum amount of work obtainable from a system or a flow of matter when it is brought to equilibrium with the reference environment [37]. The exergy consumption during a process is proportional to the entropy production due to irreversibilities. It is a useful tool for furthering the goal of more efficient energy use, as it enables the determination of the location, type, and true magnitude of energy wastes and losses in a system.

For a PEM fuel cell system, the exergetic efficiency is defined as

$$
\begin{aligned}
& \varepsilon=\frac{\text { electrical output }}{(\text { exergy })_{\text {Rxtnt }}-(\text { exergy })_{\text {Prdct }}} \\
& \varepsilon=\frac{\widehat{W}_{\text {net }}}{\left(\widehat{E}_{\mathrm{O}_{2}, R}+\widehat{E}_{\mathrm{H}_{2}, R}\right)-\left(\widehat{E}_{\mathrm{O}_{2}, P}+\widehat{E}_{\mathrm{H}_{2} \mathrm{O}, P}\right)},
\end{aligned}
$$

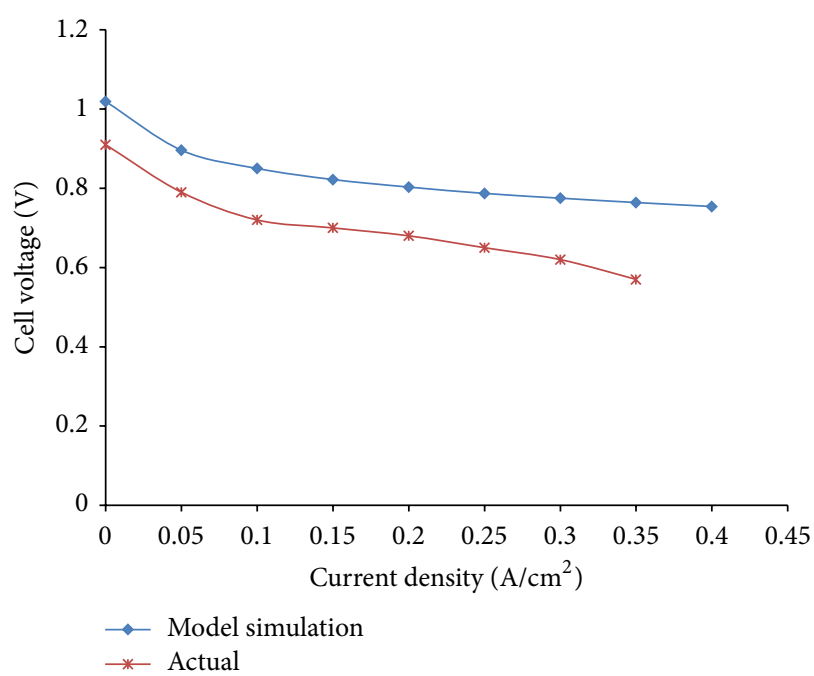

FIgURE 3: Comparative polarization curve of the simulated and literature results for PEMFC.

where $\widehat{E}_{\mathrm{O}_{2}, R}, \widehat{E}_{\mathrm{H}_{2}, R}, \widehat{E}_{\mathrm{O}_{2}, P}$, and $\widehat{E}_{\mathrm{H}_{2} \mathrm{O}, P}$ are the total exergies of the reactants, oxygen, and fuel (hydrogen), and the products oxygen and water, respectively. The net electrical power output produced by the cell is given as [40]

$$
\widehat{W}_{\text {net }}=V_{\text {cell }} \cdot I
$$

where $V_{\text {cell }}$ is the fuel cell output voltage and $I$ is the current.

The computer simulation of the model developed for theoretical energy and exergy analyses of the proton exchange membrane fuel cell is achieved using computer codes to demonstrate the performance and behaviour of the system by varying the operating parameters.

\section{Results and Discussion}

Fuel cell which can be described as a self-contained energy generation device is a reliable alternative energy for residential and industrial applications. However, despite the wide acceptance of this device as an alternative energy source that can compete favourably with the existing energy sources, the technology is yet to be commercially available. One major reason for nonavailability of fuel cells at commercial scale can be attributed to lack of understanding of the interaction between the various parameters that influence the performance of these cells. A better understanding of fuel cell technology can be achieved through predictive mathematical model, which is the focus of this study. The simulated results obtained on the influence of various parameters on the voltage output and energy and exergy of proton exchange membrane fuel cell are presented in Figures 3-15. Figure 3 represents the simulated performance of PEMFC at operating conditions of 1 atmosphere for the cathode and anode, operating temperature of $343 \mathrm{~K}$, and membrane thickness of $178 \mu \mathrm{m}$.

The results presented in Figure 3 indicate that operating single stack of proton exchange membrane fuel cell at 


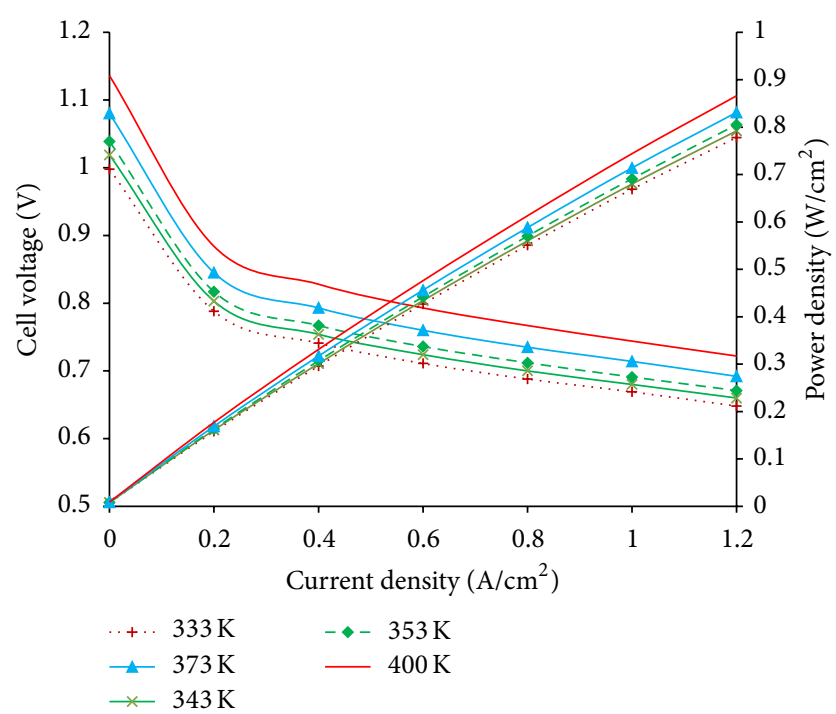

FIGURE 4: Effect of cell temperature on the voltage-current density characteristics.

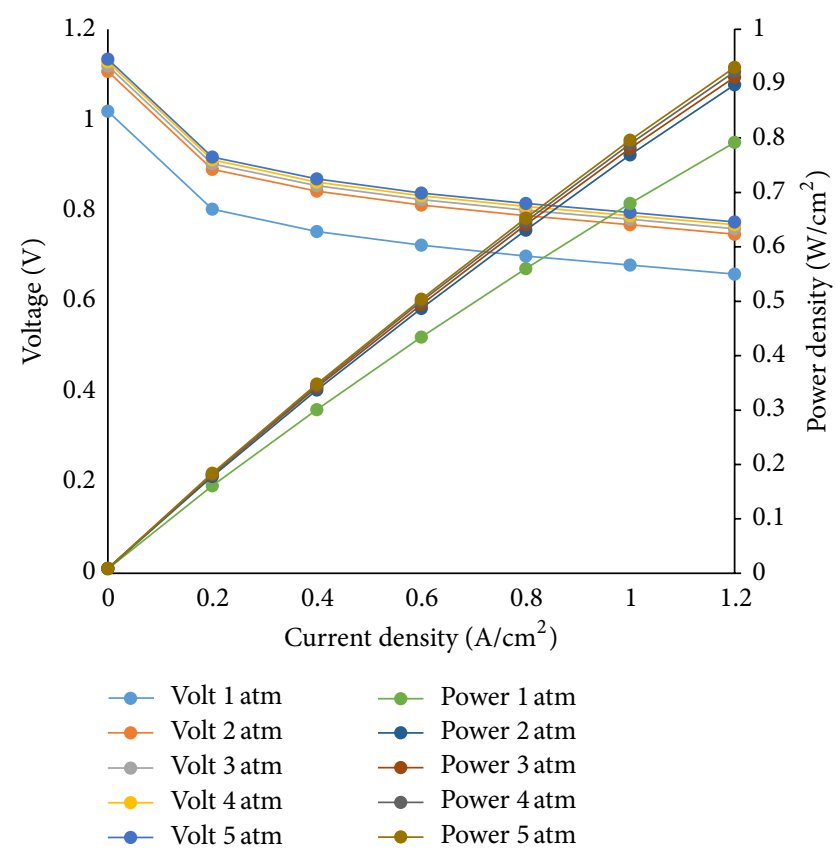

Figure 5: Effect of anode pressure on PEMFC performance.

operating conditions of 1 atmosphere, $343 \mathrm{~K}$, and membrane thickness of $178 \mu \mathrm{m}$ will produce a maximum voltage (open circuit voltage) of $1.019 \mathrm{~V}$. At a current density of $0.05 \mathrm{~A} / \mathrm{cm}^{2}$, there is a sudden reduction in voltage to $0.896 \mathrm{~V}$ after which the cell output voltage decreased gradually with increase in current density. The sudden drop in voltage as the current density increases from 0 to $0.05 \mathrm{~A} / \mathrm{cm}^{2}$ can be attributed to activation losses known as overpotentials in the cell [41]. The literature result is used to validate the results obtained from numerical simulations. The computed polarization curve is compared with the literature results of previous study by

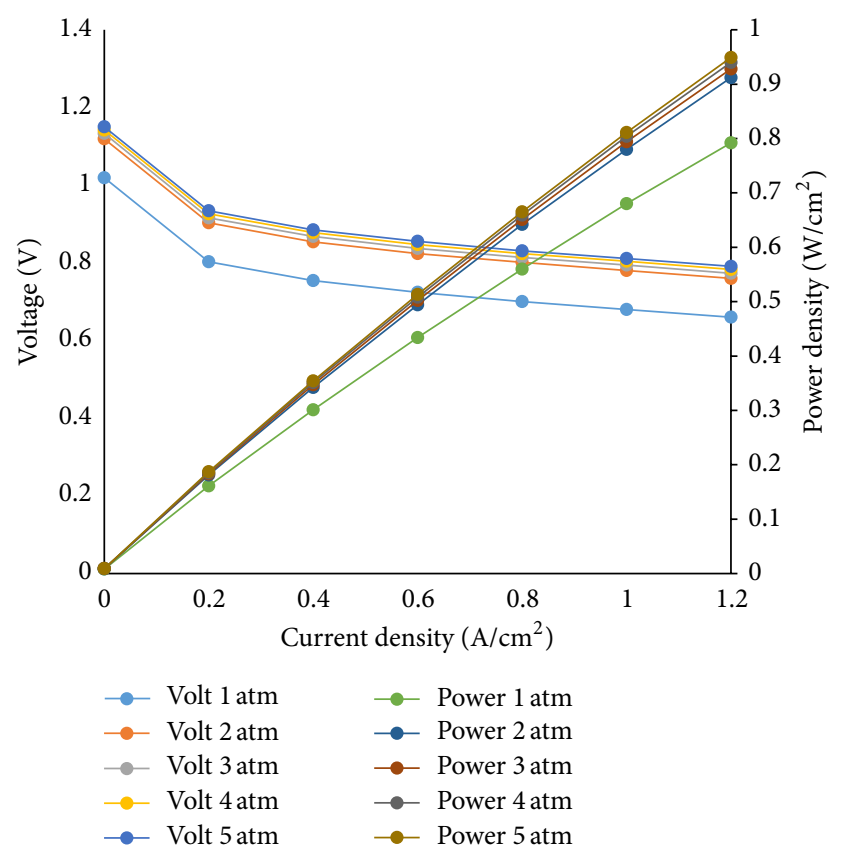

FiguRE 6: Effect of cathode pressure on PEMFC performance.

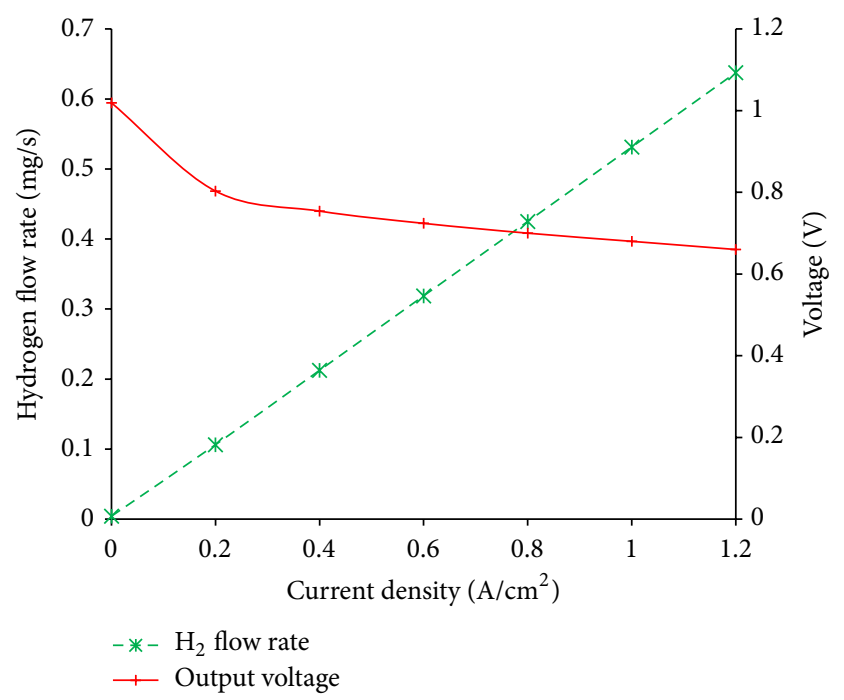

FIgURE 7: Hydrogen flow rate variations of PEMFC.

Abdulkareem [13] and the value of the correlation coefficient for both sets of data was calculated as 0.98033 , which shows that the calculated results are in good agreement with the experimental data. The variation between the simulation and experimental results could be attributed to the fact that the simulation result is an instantaneous value which measures the possible cell voltage at a given time, while the experimental results will take some time to stabilize before producing voltage. The variation can also be attributed to some assumptions made during the conceptualization of the model. For instance, the reaction in the fuel cell is incomplete and the extent of electrochemical reaction that produced 


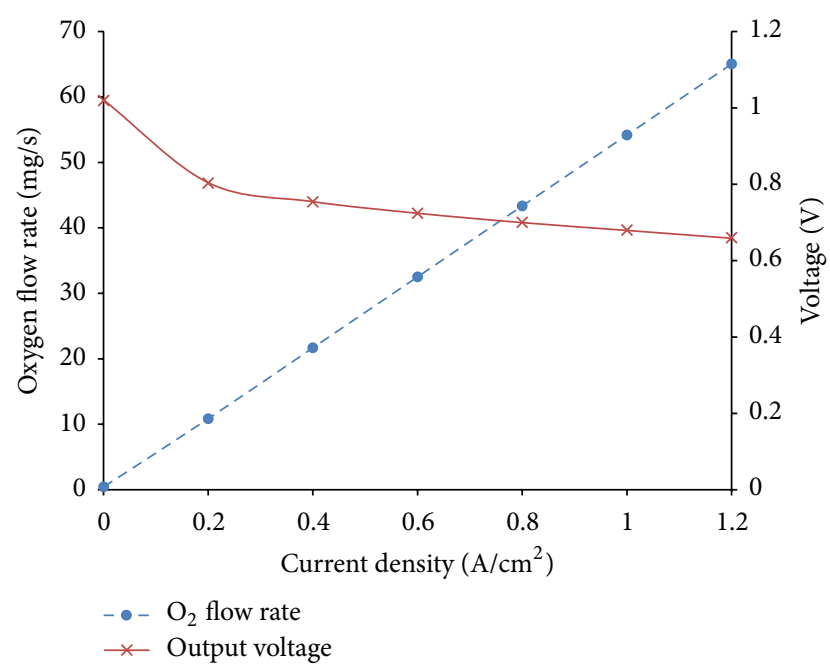

FIGURE 8: Oxygen flow rate variations of PEMFC.

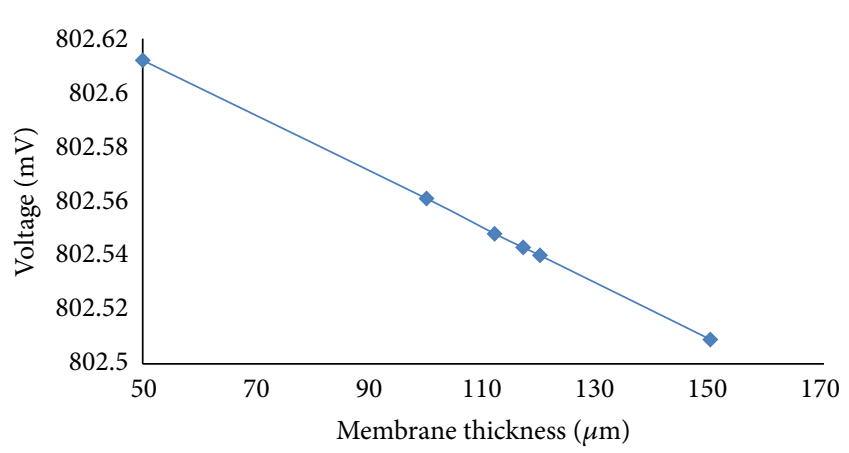

FIGURE 9: Effect of membrane thickness on voltage output.

the voltage is varied for the simulated and experimental results. It can be observed that despite the little variation between the simulated and experimental results, their polarization curves are still very similar. The model developed was further simulated to investigate the influence of operating parameters on the performance of the proton exchange membrane fuel cell fueled with hydrogen.

Aside from the inherent qualities of proton exchange membrane fuel cell, which depend on materials and manufacturing conditions, the operating conditions also affect its performance to a large extent because they can alter the shape and position of the polarization curve [28]. After validation of the simulated results with the literature values, the PEMFC model is subjected to different values of input variables in order to study their effect on the $V-I$ characteristics, the output voltage of the PEMFC, and polarization losses. The base-case operating conditions of the system temperature, anode and cathode pressures, and membrane thickness are $343 \mathrm{~K}, 1 \mathrm{~atm}$, and $178 \mu \mathrm{m}$, respectively. Figure 4 presents the temperature dependent $V-I$ characteristics of the PEMFC at operating anode and cathode pressure of $1 \mathrm{~atm}$. It has been proven that temperature has a more significant influence on the performance of the PEMFC than other operation variables [28].

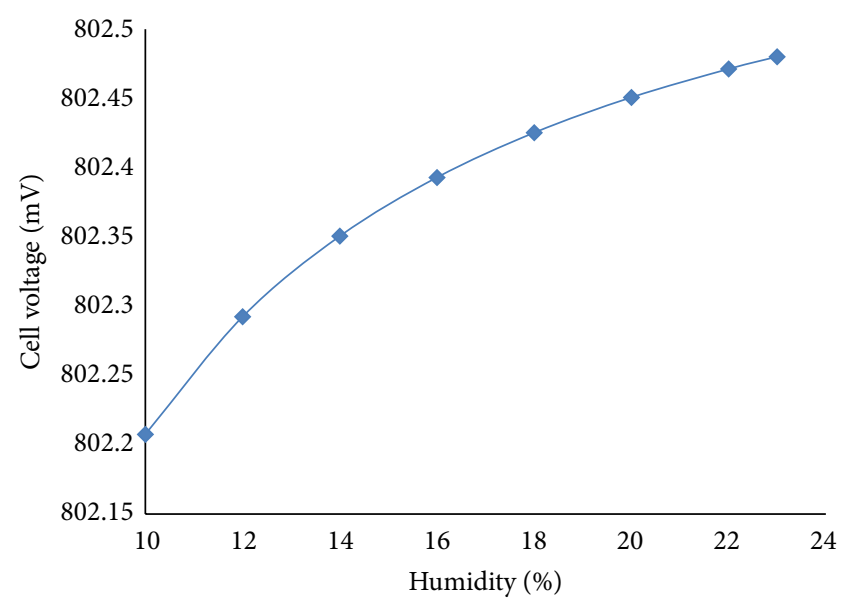

FIGURE 10: Effect of predicted membrane humidity on PEMFC performance.

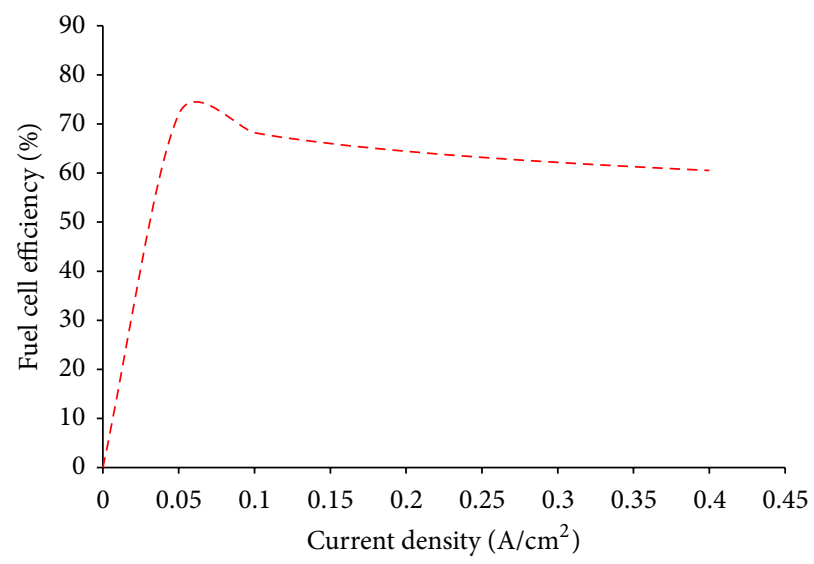

FIGURE 11: Efficiency of the PEMFC at $1 \mathrm{~atm}$ anode and cathode pressures and $343 \mathrm{~K}$ operating temperature.

From the simulated results presented in Figure 4 showing series of polarization curves at different operating temperatures, it can be seen that, with the increase in temperature from 333 to $400 \mathrm{~K}$, the PEMFC performance also increases and so does the power density. For instance, at current density of $0.2 \mathrm{~A} / \mathrm{cm}^{2}$, the cell voltage output is $0.788 \mathrm{~V}$ at $333 \mathrm{~K}$ which increases to $0.884 \mathrm{~V}$ at $400 \mathrm{~K}$. It thus implies that, for higher temperature values, the overpotentials (activation, ohmic, and concentration losses) in the PEMFC are reduced and hence the cell can operate with a higher performance [42]. The shift of the PEMFC polarization curves also indicates the improvement of electrical efficiency as temperature increases. This is due to the improvement in some parameters such as the exchange current density of the oxygen reduction reaction, membrane conductivity, reversible thermodynamic potential $E_{\mathrm{Nernst}}$, and binary diffusivities [40]. Also, the rise of the temperature increases proton mobility in the membrane and improves catalyst activity and gas diffusion [43]. With limitations to marginal improvement of the voltage at higher temperatures which result from membrane dryness and 


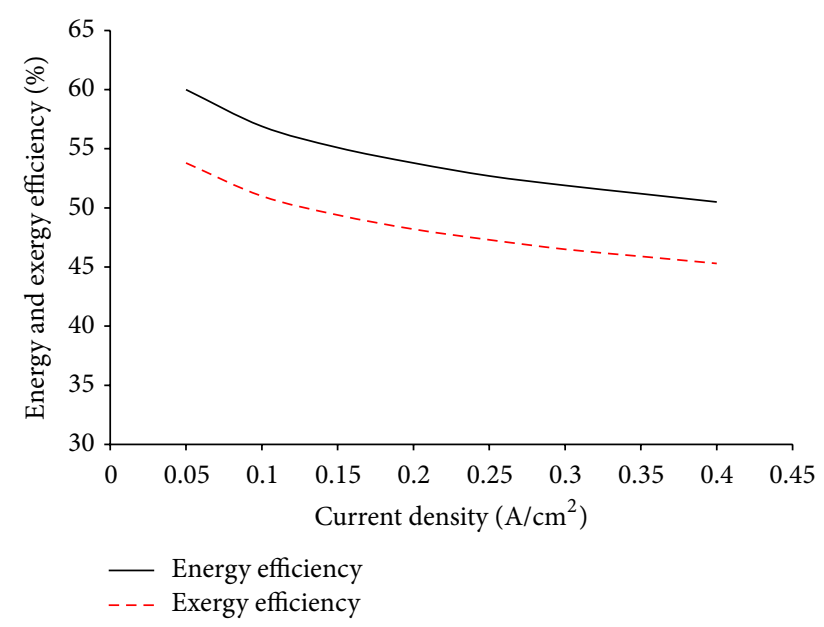

FIGURE 12: Variations of energy and exergy efficiencies of the $\mathrm{PEMFC}$ at $343 \mathrm{~K}$ and $1 \mathrm{~atm}$.

increased internal resistance, a much higher temperature is therefore beneficial for the PEMFC to improve electrical performance [40]. However, in reality, increasing the operating temperature beyond a certain limit will negatively affect the performance of fuel cell depending on the nature of the membrane. For instance, it has been reported that thermal stability of Nafion $\left(120-150^{\circ} \mathrm{C}\right)$ is a major drawback for proton exchange membrane fuel cell development. Emphasis is now placed on the development of alternative membrane with high thermal stability for the purpose of improving the fuel cell performance which is indicated by the simulated model.

Also investigated through the simulation of the developed model is the influence of anode and cathode pressure on the proton exchange membrane fuel cell performance at constant operating temperature of $343 \mathrm{~K}$. The operating pressures of anode and cathode sites also play important role in the performance of fuel cells. Figures 5 and 6 show the simulated results obtained on the influence of anode and cathode pressure, respectively, at $343 \mathrm{~K}$ cell operating temperature.

From Figures 5 and 6, it can be observed that increase in pressure of anode and cathode resulted in an increase in the output voltage of the fuel cell. The results also indicate that, at current density of $0.2 \mathrm{~A} / \mathrm{cm}^{2}$, the voltage output of the cell is $0.803 \mathrm{~V}$ at cathode pressure of $1 \mathrm{~atm}$, whereas, at the same current density but with the cathode operating pressure at $50 \mathrm{~atm}$, the voltage output is $0.934 \mathrm{~V}$. A closer observation of Figures 5 and 6 reveals that though the cell performance increased monotonously in both cases, the cathode pressure is more sensitive than anode pressure. For instance, at current density of $0.4 \mathrm{~A} / \mathrm{cm}^{2}$ and operating pressure of $50 \mathrm{~atm}$, the cell output at the cathode is $0.885 \mathrm{~V}$, with the equivalent value of $0.87 \mathrm{~V}$ at the anode. The variation in the output voltage of the cell at the same operating pressure of the anode and cathode can be attributed to the fact that the electrochemical reaction that generates power in the cell takes place at the cathode [42]. Though the simulated results reveal that increase in pressure favours the performance of fuel cells, care must be taken not to exceed the limiting operating pressure of the stack.

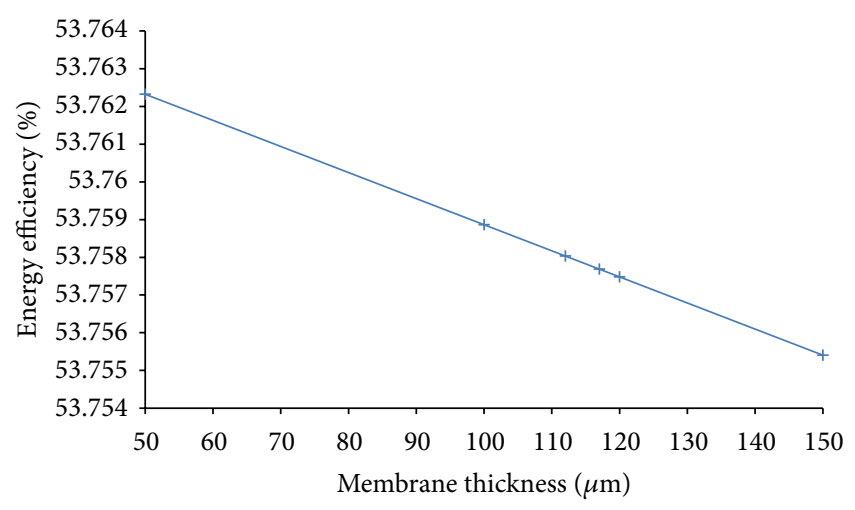

FIGURE 13: Effect of membrane thickness on energy efficiency of the PEMFC.

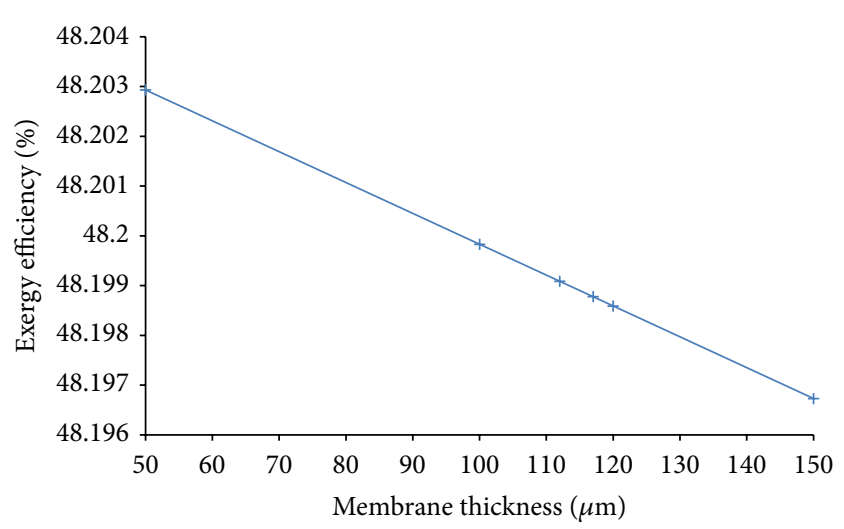

FIGURE 14: Effect of membrane thickness on exergy efficiency of the PEMFC.

Figures 7 and 8 present the simulated results on the influence of hydrogen and oxygen flow rates on the performance of proton exchange membrane fuel cell. As can be seen in these figures, more hydrogen and oxygen are consumed by the fuel cell system with increase in current density. The consumption of more fuel reduces the concentrations of hydrogen and oxygen at various points in the PEM fuel cell gas channels and increases the concentrations of these reactants at the input of the stack. The results also show that voltage output of the cell behaved contrary to the behaviour of hydrogen and oxygen flow rates with current density. Since less pressure produced less voltage, it can thus be inferred from this relationship between voltage and flow rates that more hydrogen and oxygen consumptions by fuel cell system lead to lower pressure [30], resulting in decreased output voltage. The reduction in output voltage at high flow rate can be attributed to concentration loss which is due to the change in concentration of reactants at the surface of the electrodes as the fuel is used causing reduction in the partial pressure of reactants, resulting in reduction in voltage [41].

Another factor that can affect the performance of fuel cell is the membrane thickness, proton exchange membrane functions as an ionic conductor between the anode and 


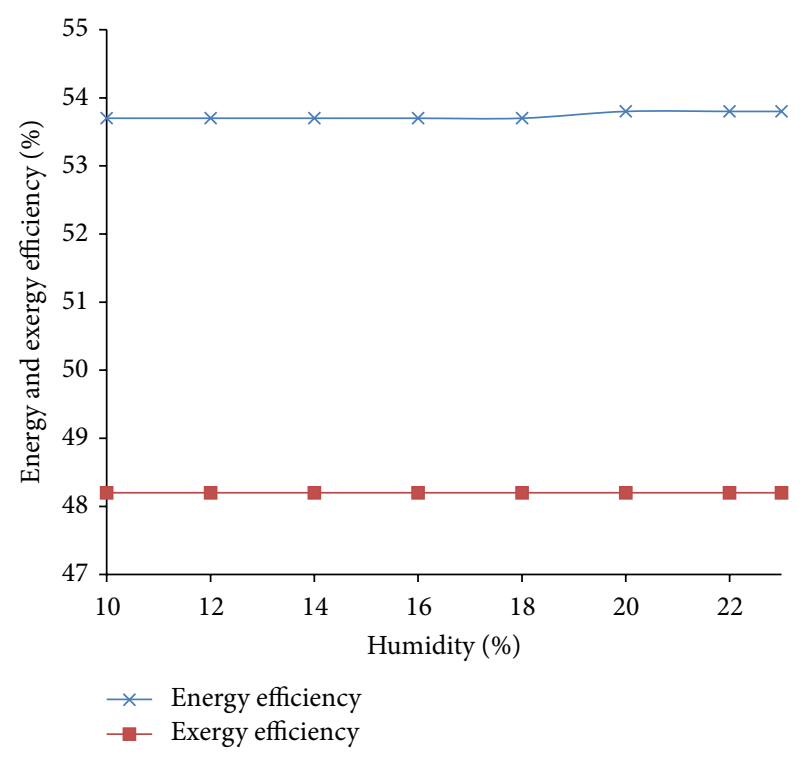

FIGURE 15: Effect of humidity on energy and exergy efficiencies.

cathode, a barrier for passage of electron, and gas cross leakage between electrodes [41]. The simulated results on the influence of membrane thickness on performance of the proton exchange membrane fuel are presented in Figure 9. The result presented is simulated at operating temperature of $343 \mathrm{~K}$, operating pressure of $1 \mathrm{~atm}$, and current density of $0.2 \mathrm{~A} / \mathrm{cm}^{2}$. It can be observed from the results in Figure 9 that membrane thickness affects the performance of the PEMFC. It can also be seen from the results that, with the membrane thickness in the range of 50 to $150 \mu \mathrm{m}$, the output voltage followed a continuous reduction pattern. This shows that, for larger values of membrane thickness, the voltage decreases with increasing membrane thickness and hence reductions in PEMFC performance. This is because ohmic loss increases with increase in membrane thickness. This loss occurs due to the electrical resistance of the electrodes and the resistance to the flow of ions in the electrolyte. Because it represents the resistance to the transfer of protons through the membrane [41], greater membrane thicknesses will favour ohmic loss which results in decrease in output voltage.

Also affecting the performance of proton exchange membrane fuel cell is the membrane humidity. For effective performance of the proton exchange membrane fuel cell, there is a need to properly control the membrane humidity, because lack of proper management of membrane humidity could lead to voltage degradation and reduction in the fuel cell durability [16]. Figure 10 shows the simulated effect of membrane humidity on the cell performance.

Though there is no term for direct representation of membrane humidity in the developed model of PEMFC in this study, the term $\lambda$ is considered as an adjustable parameter which depends on membrane humidity and stoichiometric ratio of anode feed gas having value between 10 and $23 \%$. Thus, its value was varied between 10 and $23 \%(10,12,14$,
$16,18,20,22$, and $23 \%$ ) in order to study its effect on cell voltage. It can be seen that the output voltage increased with increase in $\lambda$. This predicts that membrane humidity has influences on the performance of the PEMFC. It has been reported that water uptake affects the ionic conductivity of membrane; in fact it was reported that when the water uptake by the membrane is too low, the ionic conductivity of the membrane will be low and this will enhance the methanol permeability $[1,10]$. However, high water uptake though improves the ionic conductivity of the membrane but with high possibility of loss of dimensional stability of the membrane. It is also worth mentioning that fuel cells as a device for energy conversion convert chemical energy to electrical energy with heat and water as the only by-product. Hence, in addition to humidification of the membrane, the device also generates water and hence the need to regulate the process of humidification of the membrane. Attempts were also made in this study to extend the humidity beyond $23 \%$; the output obtained was negative indicating that at higher humidity the ionic conductivity of the membrane is negatively affected.

3.1. Analyses of Energy and Exergy Efficiencies. The processes that involve heat are highly inefficient from the point of view of the second law analysis. This is because the exergy value of heat is often much lower than its energy value, particularly at temperatures close to ambient temperature. The exergy analysis provides information on how effective a process takes place towards conserving natural resources [23]. This makes it possible to identify areas in which technical and other improvements could be undertaken. It also indicates the priorities that could be assigned to conservation procedures. Cognizance of exergy utilization of energy sources would help advance technological development towards resourcesaving and efficient technology can be achieved by improving design of processes with high exergetic efficiency. Further, application of exergy analysis in design and development of sustainable processes provides information for long-term planning of resource management.

The efficiency of a system can be defined in various ways. Conventionally, it is based upon the maximum energy obtainable from a fuel by burning it, called the heating or calorific value. For a fuel cell, the energy available is called the Gibbs energy and represents the maximum amount of electricity that can be gained from the cell. The Gibbs energy is smaller than the calorific value. Fuel cell efficiencies related to Gibbs energies are nearly always $100 \%$. Thus, efficiency is normally defined as the electrical energy extracted divided by the calorific value of the fuel. This enables fuel cells to be compared directly to combustion-based processes but places an upper limit on fuel cell efficiencies due to the chemical properties of the fuel. A hydrogen fuel cell operating at $25^{\circ} \mathrm{C}$, for instance, has a maximum theoretical efficiency of $83 \%$ [29], even when the fuel cell is extracting all the electrical energy possible. This compares to a maximum theoretical efficiency in a combustion engine at $500^{\circ} \mathrm{C}$ of $58 \%$. Figure 11 shows the efficiency variation of the PEMFC with current density. 
Figure 11 indicates that the fuel cell efficiency increased with increase in current density until a maximum of $75 \%$ was attained. The maximum fuel cell efficiencies typically range from 60 to $80 \%$. After the maximum efficiency of $75 \%$, a gradual decrease is noticeable which can be attributed to the fact that, at initial condition, the system consumes more power than its production. This affects the efficiency and causes the increase until the first loading at $0.05 \mathrm{~A} / \mathrm{cm}^{2}$. After the power demand of resistive load starts, the efficiency decreases due to voltage losses and parasitic power consumption [30].

3.2. Energy and Exergy Efficiencies. The energy and exergy analyses of the fuel cell system are carried out to evaluate the fuel cell efficiency. Figure 12 shows the variations of energy and exergy efficiencies with current density. In this study, the energy efficiency obtained is between 50.5 and $68.2 \%$ for $0-0.40 \mathrm{~A} / \mathrm{cm}^{2}$ current density, while exergy efficiencies vary from 45.3 to $61.2 \%$. Both energy and exergy efficiencies decreased with increase in current density because of the reactants' flow rates and hydrogen pressure [30]. It is also observed from the results on this Figure that the energy and exergy efficiency curves behave similar to the polarization curves; the influences of voltage losses are obvious. Therefore, improved performance through higher energy and exergy efficiencies can be achieved if the voltage losses are greatly minimized. This can be done by operating the PEMFC at moderate temperatures and pressures.

The comparative plots of the variations of energy and exergy efficiencies with current density as shown in Figure 12 also establish the second law of thermodynamics which explains exergy as "useful work." Not all energy from the fuel cell system is useful; hence, exergy efficiency is less than energy efficiency. Also investigated through simulation of the model is the effect of membrane thickness on energy and exergy efficiencies of proton exchange membrane fuel cell and results obtained are presented in Figures 13 and 14.

It can be observed from these Figures (Figures 13 and 14) that energy and exergy efficiencies decreased with increase in membrane thickness between 50 and $150 \mu \mathrm{m}$. This is because large membrane thicknesses will favour ohmic voltage losses resulting in lower output voltage and hence poor performance. Again, this implies that large membrane thicknesses are disadvantageous to the fuel cell performance.

The effect of membrane humidity of PEMFC on energy and exergy efficiencies is also simulated and the results obtained are illustrated in Figure 15. As seen in this figure, membrane humidity has an influence on the performance of the PEMFC. The energy and exergy efficiencies increased with increase in membrane humidity. This is because as the humidity increases, the cell output voltage also increases leading to higher efficiencies. The excess water removal causes membrane drying, resulting in increased ionic resistance and thus decreasing the electrical efficiency, which in turn results in further drying of the membrane (hot spots) [25]. On the other hand, the excess water stored in the membrane resulted in cell flooding. In order to avoid degradation of voltage and to extend fuel cell stack life, membrane humidity must be controlled properly [25].

\section{Conclusions}

A mathematical model representing a proton exchange membrane fuel cell unit was developed and validated by comparing the polarization curves obtained with the one in open literature. A parametric study was also conducted to examine the effect of various operating conditions on the performance and energy and exergy efficiencies of the cell. The analyses of the results obtained indicated that operating temperature, pressure, membrane thickness, and reactants' flow rates influenced the performance of the PEMFC as revealed by the developed model. The results obtained from the numerical simulation of the developed model are found to be in good agreement with the experimental data available in the literature; thus the model developed can accurately represent the performance specifications of the system over the entire range of system operation. The energy and exergy efficiencies of the PEMFC can be improved by having a higher operating pressure. However, a high pressure difference between the cathode and the anode is recommended in order to enhance the electroosmotic drag phenomena between the two electrodes. The efficiency of the fuel cell can also be enhanced by increasing the fuel cell operating temperature despite the small and low temperature range of a PEMFC as opposed to other types of fuel cells that operate at high temperatures. Higher exergetic efficiency could be attained if the fuel cell operates at relatively higher cell voltages that would require less mass flow rates for the reactants and the products to achieve a high electrical output. Generally, high performance can be achieved from the extended model results by significant improvement of the fuel cell through adopting any or a combination of the different optimum operating conditions. Any increase in the system performance will greatly affect the overall efficiency and will contribute to the growth of the fuel cell systems in various markets.

\section{Competing Interests}

The authors declare that they have no competing interests.

\section{Acknowledgments}

University Board of Research (UBR) and STEP-B project of the Federal University of Technology Minna, Nigeria, are highly appreciated for their supports.

\section{References}

[1] A. S. Abdulkareem, A. S. Afolabi, C. A. Idibie, H. C. Pienaar, and S. E. Iyuke, "A predictive model for the energy analysis of a proton exchange membrane fuel cell by computer simulation," Energy Sources, Part A: Recovery, Utilization, and Environmental Effects, vol. 35, no. 1, pp. 32-41, 2013.

[2] A. S. Abdulkareem, A. Jimoh, A. S. Afolabi, E. Muzenda, and A. C. Okeke, "Predictive mathematical modeling and computer simulation of direct ethanol fuel cell," Energy Sources, Part A: Recovery, Utilization and Environmental Effects, vol. 38, no. 5, pp. 635-643, 2016. 
[3] X. Li, Principles of Fuel Cells, Taylor and Francis Group, New York, NY, USA, 1st edition, 2006.

[4] J. O. Odigure, A. S. Abdulkareem, and O. D. Adeniyi, "Computer simulation of soil temperature due to heat radiation from gas flaring," Association for the Advancement of Modelling and Simulation in Enterprises, vol. 72, no. 6, pp. 1-10, 2003.

[5] M. Ahmad, S. Samuel, M. Zafar et al., "Physicochemical characterization of Eco-friendly rice Bran oil biodiesel," Energy Sources, Part A: Recovery, Utilization and Environmental Effects, vol. 33, no. 14, pp. 1386-1397, 2011.

[6] J. S. Yi and T. Van Nguyen, "Multicomponent transport in porous electrodes of proton exchange membrane fuel cells using the interdigitated gas distributors," Journal of the Electrochemical Society, vol. 146, no. 1, pp. 38-45, 1999.

[7] J. H. Lee, T. R. Lack, and A. J. Appleby, "Modeling electrochemical performance in large scale proton exchange membrane fuel cell stacks," Journal of Power Sources, vol. 70, no. 2, pp. 258-268, 1998.

[8] D. Cheddie and N. Munroe, "Review and comparison of approaches to proton exchange membrane fuel cell modeling," Journal of Power Sources, vol. 147, no. 1-2, pp. 72-84, 2005.

[9] M. Shibasaki, T. Yachi, and T. Tani, "A new direct methanol fuel cell with a zigzag-folded membrane electrode assembly," Journal of Power Sources, vol. 145, no. 2, pp. 477-484, 2005.

[10] S. E. Iyuke, A. B. Mohamad, A. A. H. Kadhum, W. R. W. Daud, and C. Rachid, "Improved membrane and electrode assemblies for proton exchange membrane fuel cells," Journal of Power Sources, vol. 114, no. 2, pp. 195-202, 2003.

[11] M. Bischoff, "Large stationary fuel cell systems: status and dynamic requirements," Journal of Power Sources, vol. 154, no. 2, pp. 461-466, 2005.

[12] B. Smitha, S. Sridhar, and A. A. Khan, "Synthesis and characterization of proton conducting polymer membranes for fuel cells," Journal of Membrane Science, vol. 225, no. 1-2, pp. 63-76, 2003.

[13] A. S. Abdulkareem, Design and development of proton exchange membrane from PSBR and carbon nanoballs for PEM fuel cell application [Ph.D. thesis], University of the Witwatersrand, Johannesburg, South Africa, 2009.

[14] H. Bashir, A. Linaries, and J. L. Acosta, "Heterogeneous sulfonation of blend systems based on hydrogenated poly(butadienestyrene) block copolymer. Electrical and structural characterization," Solid State Ionics, vol. 139, no. 3-4, pp. 189-196, 2001.

[15] M. K. Song, Y. T. Kim, and J. M. Fentom, "Chemically-modified Nafion/Poly (vinylidene fluoride) blend ionomers for proton exchange membrane fuel cells," Journal of Polymer Science, vol. 117, pp. 114-121, 2003.

[16] E. Chen, W. Chen, G. Sun et al., "Test on the degradation of direct methanol fuel cell," Electrochimica Acta, vol. 51, no. 12, pp. 2391-2399, 2006.

[17] K. Sopian and W. R. Wan Daud, "Challenges and future developments in proton exchange membrane fuel cells," Renewable Energy, vol. 31, no. 5, pp. 719-727, 2006.

[18] I. B. Hussein, M. Z. B. Yusoff, and M. H. Boosroh, "Exergy analysis of a $120 \mathrm{MW}$ thermal power plant," in Proceedings of the 1st BSME-ASME International Conference on Thermal Engineering, p. 177, Dhaka, Bangladesh, 2001.

[19] G. Crawley, "Proton exchange membrane (PEM) fuel cells: opening doors to fuel cell commercialization," Fuel Cell Today, pp. 1-12, 2006.

[20] Z. Houcheng, S. Shanhe, L. Guoxing, and C. Jincan, "Efficiency calculation and configuration design of a PEM electrolyzer system for hydrogen production," International Journal of Electrochemical Science, vol. 7, pp. 4143-4157, 2012.

[21] C. Mborah and E. K. Gbadam, "On the energy and exergy analysis of a $500 \mathrm{~kW}$ steam power plant at Benso Oil Palm Plantation (BOPP)," Research Journal of Environmental and Earth Sciences, vol. 2, no. 4, pp. 239-244, 2010.

[22] W.-M. Yan, C.-Y. Chen, S.-C. Mei, C.-Y. Soong, and F. Chen, "Effects of operating conditions on cell performance of PEM fuel cells with conventional or interdigitated flow field," Journal of Power Sources, vol. 162, no. 2, pp. 1157-1164, 2006.

[23] Z. S. Ahmet, Importance of exergy analysis in industrial processes [Ph.D. thesis], King Fahd University of Petroleum and Minerals, Dhahran, Saudi Arabia, 2004.

[24] C. Brian, An Introduction to Fuel Cells and Hydrogen Technology, Heliocentris, Vancouver, Canada, 2001.

[25] T. Uma, Nonlinear state estimation in polymer electrolyte membrane fuel cells [M.S. dissertation], Cleveland State University, Cleveland, Ohio, USA, 2008.

[26] A. Rezazadeh, M. Sedighizadeh, and M. Karimi, "Proton exchange membrane fuel cell control using a predictive control based on neural network," International Journal of Computer and Electrical Engineering, vol. 2, article 1, 2010.

[27] R. O’Hayre, S. W. Cha, W. Colella, and F. B. Prinz, Fuel Cell Fundamentals, John Wiley \& Sons, New York, NY, USA, 2005.

[28] R. Chris and S. Scott, Introduction to Fuel Cell Technology, Department of Aerospace and Mechanical Engineering, University of Notre Dame, Notre Dame, Ind, USA, 2003.

[29] R. Baker and Z. Jiujun, "Proton exchange membrane or Polymer Electrolyte Membrane (Pem) fuel cells," Electrochem Encyclopedia, vol. 1, pp. 11-22, 2011.

[30] A. Yilanci, I. Dincer, and H. K. Ozturka, "Performance analysis of a PEM fuel cell unit in a solar-hydrogen system," International Journal of Hydrogen Energy, vol. 33, no. 24, pp. 7538-7552, 2008.

[31] J. Larminie and A. Dicks, Fuel Cell Systems Explained, John Wiley \& Sons, New York, NY, USA, 2nd edition, 2003.

[32] A. C. Yunus and A. B. Michael, Thermodynamics: An Engineering Approach, 5th edition, 2007.

[33] R. B. Bird, W. E. Stewart, and E. N. Lightfoot, Transport Phenomena, John Wiley \& Sons, New York, NY, USA, 2nd edition, 2002.

[34] E. Himmelblau and A. Lesdon, Optimization of Chemical Engineering Processes, McGraw-Hill Chemical Engineering Series, McGraw-Hill, 2nd edition, 2001.

[35] M. Bogani, Analysis of proton exchange membrane fuel cell by computer simulation [M.S. thesis], University of the Witwatersrand, Johannesburg, South Africa, 2009.

[36] S. Ivar, Sensitivity of the Chemical Exergy for Atmospheric Gases and Gaseous Fuels to Variations in Ambient Conditions, Department of Energy and Process Engineering, Norwegian University of Science and Technology, Trondheim, Norway, 2006.

[37] V. Amir, N. Aminreza, G. Mohammad, and V. Sadegh, "Exergy concept and its characterization," International Journal of Multidisciplinary Sciences \& Engineering, vol. 2, pp. 47-51, 2011.

[38] S. Masanori and H. Abdelaziz, "Introduction to the concept of exergy-for a better understanding of low-temperature-heating and high-temperature-cooling systems," Research Notes, vol. 2158, p. 45, 2002.

[39] A. Kazim, "Exergy analysis of a PEM fuel cell at variable operating conditions," Energy Conversion \& Management, vol. 45, no. 11-12, pp. 1949-1961, 2004. 
[40] M. Miansari, K. Sedighi, M. Amidpour, E. Alizadeh, and M. O. Miansari, "Experimental and thermodynamic approach on proton exchange membrane fuel cell performance," Journal of Power Sources, vol. 190, no. 2, pp. 356-361, 2009.

[41] R. Seyezhai and B. L. Mathur, "Mathematical modeling of proton exchange membrane fuel cell," International Journal of Computer Applications, vol. 20, no. 5, pp. 1-6, 2011.

[42] M. Tafaoli-Masoule, M. Shakeri, and A. Bahrami, "Process parameters for maximum power of a proton exchange membrane fuel cell," Journal of Petroleum and Gas Engineering, vol. 3, no. 2, pp. 16-25, 2012.

[43] P. Margalef, On the poly-generation of electricity, heat and hydrogen with high temperature fuel cells [Ph.D. thesis], University of California, Irvine, Irvine, Calif, USA, 2010. 

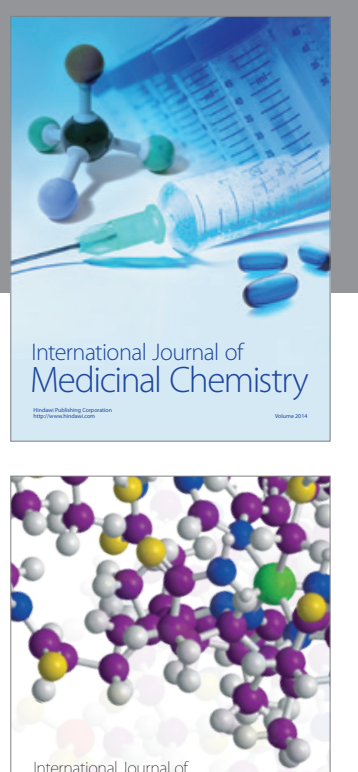

Carbohydrate Chemistry

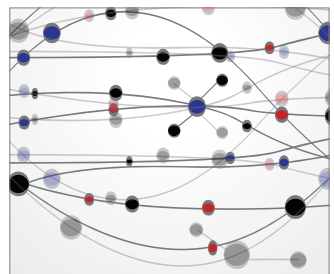

The Scientific World Journal
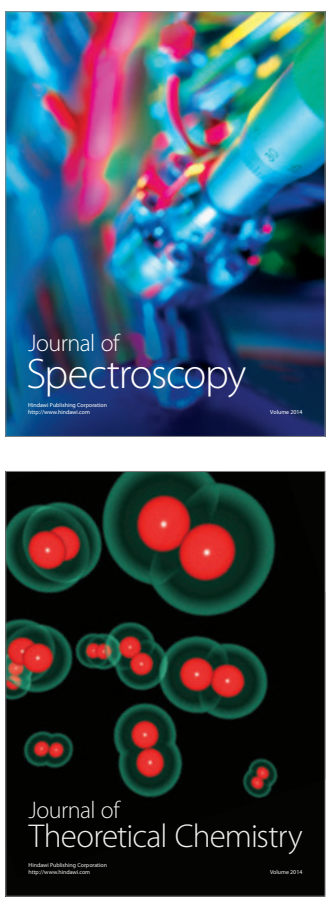
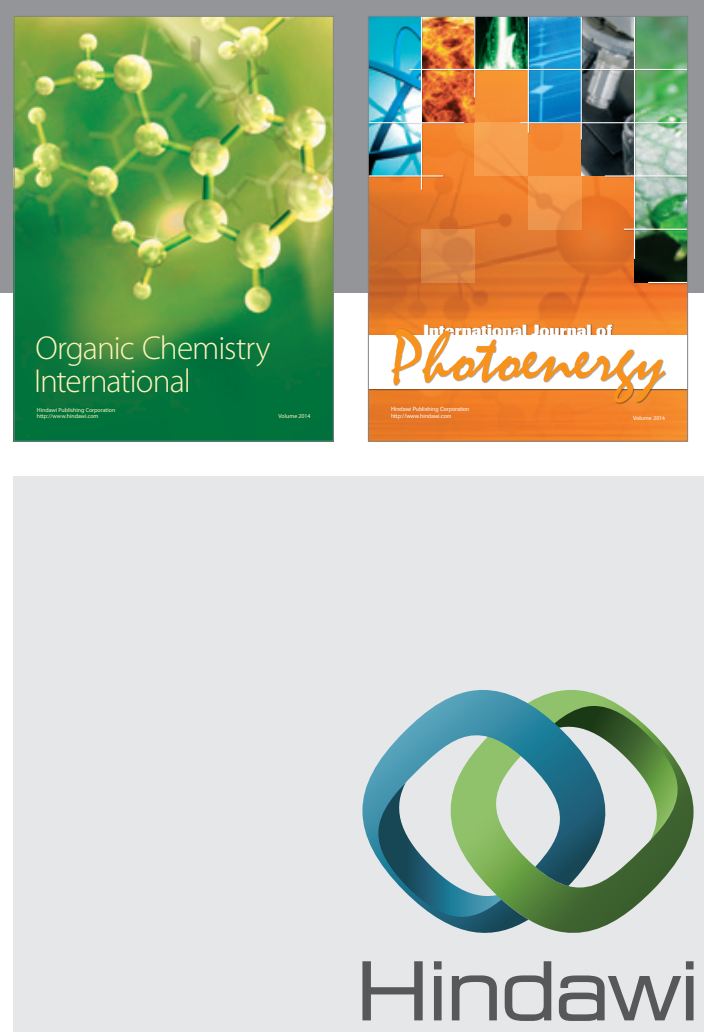

Submit your manuscripts at

http://www.hindawi.com

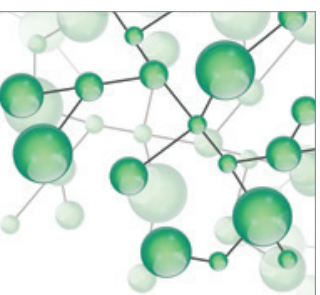

International Journal of

Inorganic Chemistry

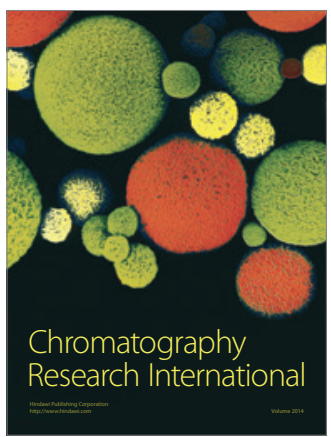

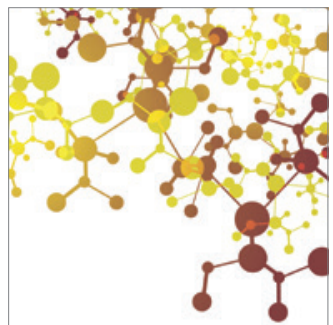

Applied Chemistry
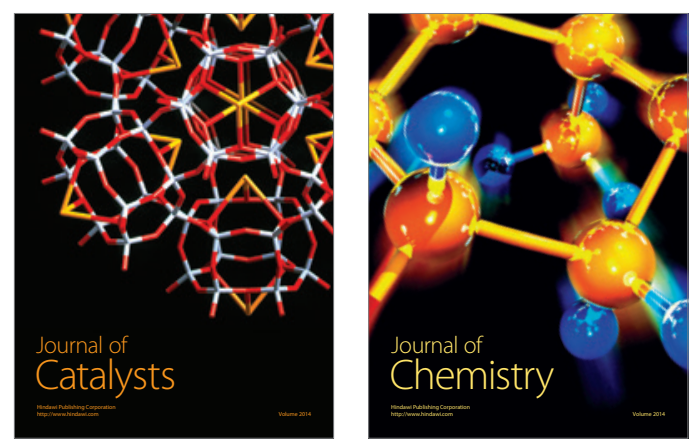
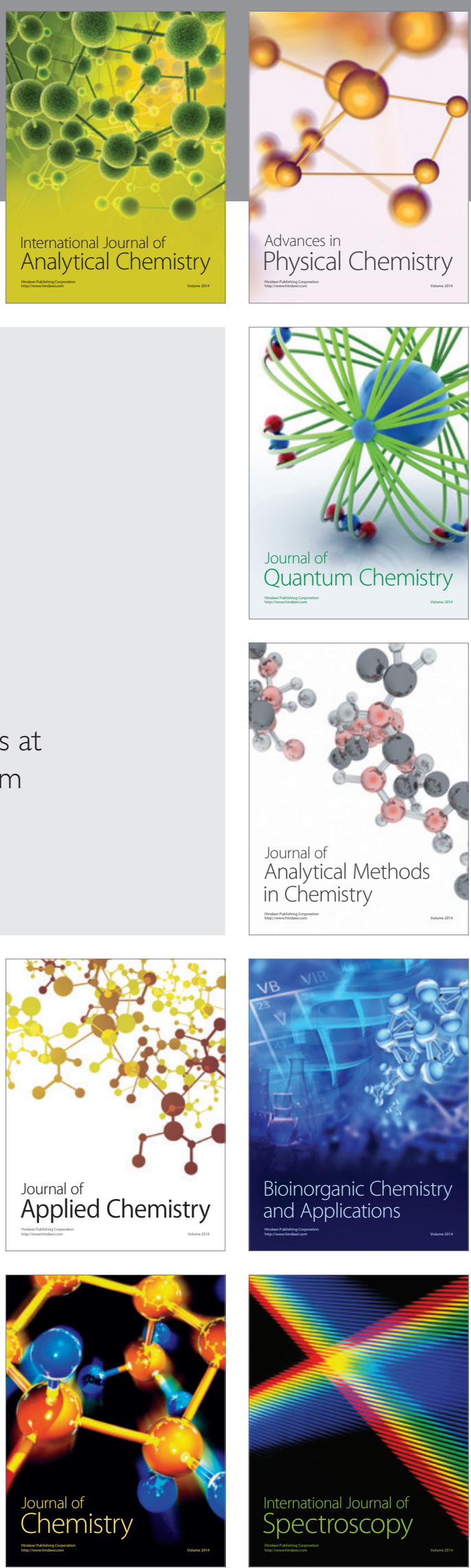